\title{
Chapter 13 \\ Union Organising in the Context of Regional Labour Market Decline: The Case of Nautilus International
}

\author{
Victor Oyaro Gekara
}

\section{Introduction}

Over the past few decades the impact of globalisation on society and industry at the national level has been immense and has been studied and extensively documented in the literature. Some of the major benefits and losses accruing from economic globalisation, particularly since the late 1970s have been debated by dominant political economy commentators (see e.g. Harvey 2005; Held et al. 1999; Strange 1996; Scholte 2000; Stiglitz 2002; Giddens 2002; Chomsky 2017). An important aspect of the globalising process has been the extensive restructuring of production and distribution patterns in search of cheaper resources, through aggressive outsourcing and offshoring. The result for many national economies, particularly advanced industrial states, has been a drastic decline in traditional industries affecting both labour and capital (Dunning 1993; Beck 2005; Perraton 2019). This chapter examines the decline in the seafaring labour markets of the so-called Traditional Maritime Countries (TMN), and the implications for union organising focusing on the UK and its seafaring labour. It examines the creation of Nautilus International (NI) Union via a merger of unions for maritime professionals across different countries in Europe initially beginning with Great Britain, the Netherlands and later Switzerland. This was a uniquely strategic response to declining membership and weakening organising capacity. Some of the key challenges associated with unions trying to organise and represent their members in the context of industrial and labour market decline are explored.

The particular focus in this chapter is the decline in the national seafaring labour markets of European Traditional Maritime countries such as Britain, Germany,

\footnotetext{
V. O. Gekara $(\bowtie)$

School of Accounting, Information Systems and Supply Chains, RMIT University, Melbourne, VIC, Australia

e-mail: victor.gekara@rmit.edu.au
} 


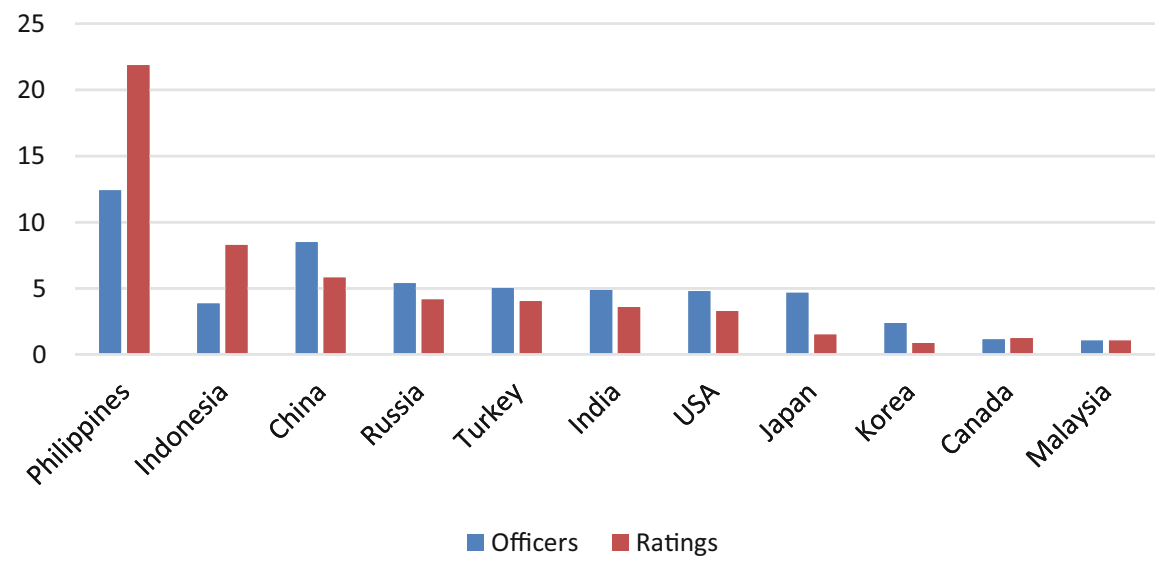

Fig. 13.1 Eleven top seafarer supply countries as of 2003. Source: Adapted and recreated by author from APEC accreditation of seafarer manning agencies project, 2005

Netherlands and Denmark. This resulted, from economic globalisation and deregulation within national economies in response to emerging neoliberal government policies in the 1980s and 1990s. (McConville 1999; Gekara 2010b). The seafaring labour market follows the hierarchical structure of the crew on-board ships and is broadly divided into two segments: officers and ratings. Senior staff responsible for the commercial and technical management of the ship are drawn from the officers' market segment, while ratings, i.e. lower level operational staff, are recruited from the ratings' market segment. The discussion here specifically relates to officers. Thus, use of the term 'seafarers' will in most cases, unless otherwise qualified, be in reference to officers.

As cheaper sources of seafaring labour opened up in low-cost developing regions, many European ship owners opted to recruit their crew from countries such as the Philippines, China, India and Indonesia and, with time, almost entirely abandoned their local labour markets. Figure 13.1 shows that by the end of the twentieth century, the majority of seafarers, both officers and ratings originated from developing countries. Note that no Western European country is represented in the top 10 list of seafarer supply by this time, and the only European country on the list, Russia, is comparatively low-cost. From the OECD, only the US, Korea and Canada appear, albeit, with very small numbers.

In the UK this shift in the supply of seafarers inevitably led to a general weakening of the labour market just as had occurred in many other similar countries. Employment opportunities for national seafarers shrank with shipping companies reducing investment in recruitment and training activities. Eventually there was a general decline of interest in the occupation even in areas that had always been considered as traditional seafaring communities such as Glasgow, Liverpool, Aberdeen and Southampton (see Gekara 2010a). With regard to labour organisation and representation, the unions acting for seafarers experienced a drastic decline in their membership and, by extension, their financial and political influence. It is within this 
context that this chapter describes the way in which three Unions, representing seafarers in North Western Europe, sought to revitalise their position through a unique form of cross-border amalgamation into a single union known as Nautilus International (NI). The chapter draws on a qualitative social science study, which was designed to examine the limitations of local policy responses to globalisationinduced problems. The research examined the waning of British shipping as a result of processes of economic globalisation and deregulation in the 1980s and 1990s and the impact of locally designed and implemented policy responses, predominantly the tonnage tax initiative. An important aspect of the study was the decline in British seafaring and the implications for, and response from, local maritime unions.

In the following sections I examine this decline as part of the overall global economic and regulatory shifts that led to an unlikely initiative by the union leaders, the process and result of their efforts, the challenges involved in the process, and conclude with an assessment of its success and conjecture as to its future.

\section{The British Seafaring Labour Market in Decline}

The globalised nature of the shipping industry has been analysed extensively, with the consistent conclusion that, undeniably, it stands out as exemplar of industrial globalisation and corporate foot-looseness (DeSombre 2006). Often highlighted is the international ownership of shipping capital and the means by which it is operated, the global nature of crew sourcing and employment and the ease with which a ship's nationality can be shifted from state to state (Alderton et al. 2004; Sampson and Schroeder 2006). As Kahveci and Nichols (2006) observe, ownership and nationality of ships are both vague and fictitious because they are increasingly difficult to ascertain and can be switched and shifted with extreme ease. Whereas this arrangement presents enormous benefits for business, in this case ship-owners, the impact for labour has been a significant decrease in resources, political influence and bargaining power (Lillie 2006; DeSombre 2006; Gekara 2010b).

Whilst many seafarers are employed on the international labour market, within Europe there nevertheless remains a relationship between the numbers of domestic seafarers in employment and the size of the national registered fleet. A number of factors are at play here including the nature and structure of the internal labour market, the training opportunities available including funding and access to training institutions, and also perceived career prospects. As highlighted previously from the mid-1970s the British shipping industry was in decline across all major aspects, including the registered fleet.

As illustrated in Fig. 13.2, the UK fleet steadily declined from 1976 through to the end of the century as a result of ship owners flagging out their vessels away from the national registers of advanced industrial maritime countries. This resulted from the fact that they were considered more stringently regulated and costlier to operate from than low-cost flags in developing regions (for an in-depth discussion of the flagging out phenomenon refer to Carlisle 1981; Metaxas 1985). 


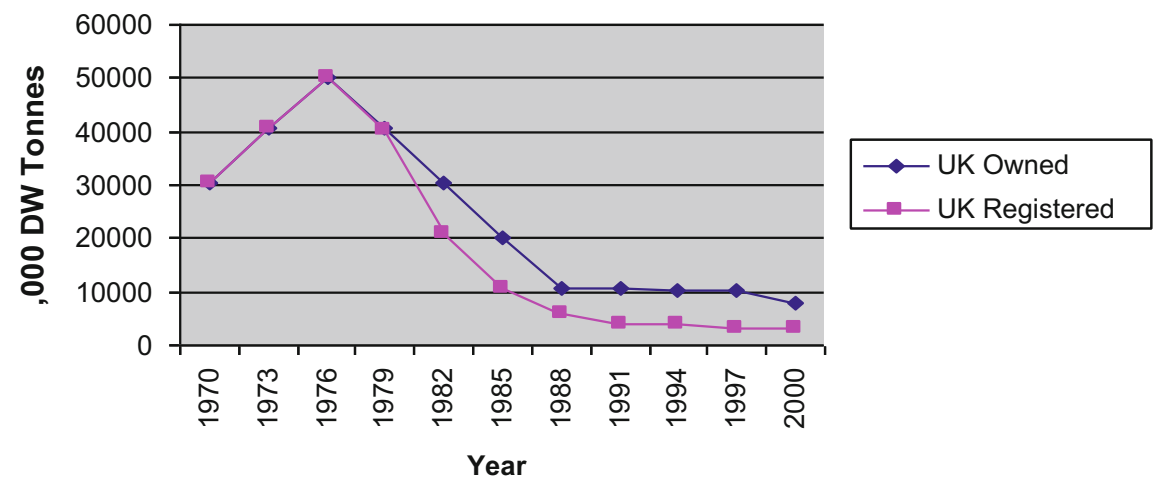

Fig. 13.2 UK owned and registered fleet 1970 to 2000. Source: UK Chamber of Shipping. (Adapted and recreated by author from Brownrigg et al. 2001)

\section{Source: UK Chamber of Shipping}

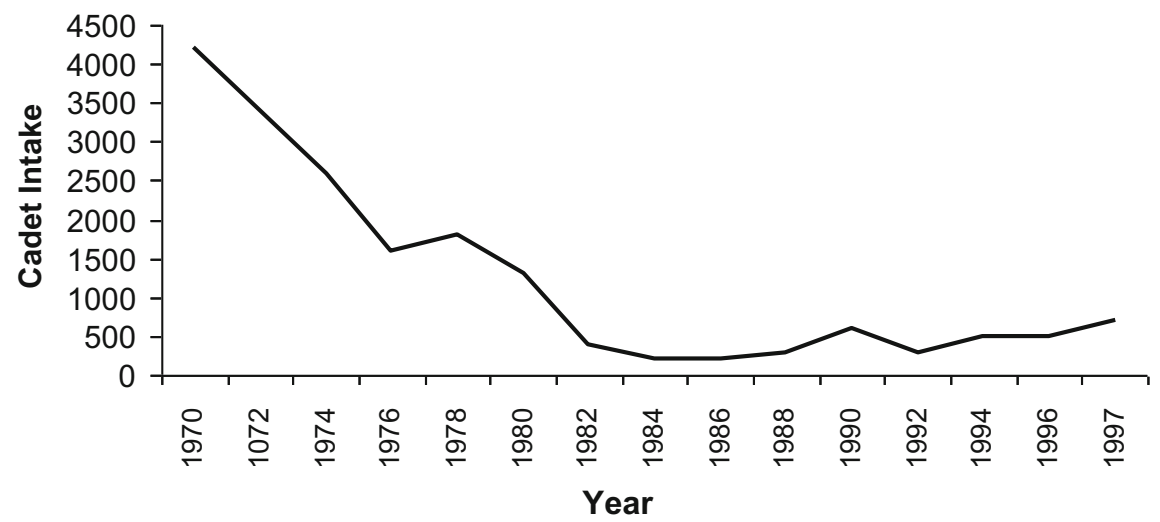

Fig. 13.3 Recruitment of cadets between 1970 and 1997. Adapted and recreated by author from Gardner et al. (2001)

Since ship owners in the UK traditionally bear much responsibility for recruiting and training cadets, as well as providing employment for qualified officers, flagging out has resulted in a corresponding decline in training funding, training opportunities and, even more problematically, employment opportunities for British seafarers. Consequently, as Fig. 13.3 illustrates, the impact of the decline in the national fleet was to cause a considerable reduction in the numbers of cadets recruited annually. This fell from about 4300 in 1970 to about 1000 cadets per year from the mid-1980s onwards.

Similarly, a survey of the number of officers employed on the UK fleet between 1980 and 1998 (Fig. 13.4) confirms the above observations as the number dropped steadily from around 25,800 in 1980 to about 9000 in 1991 then levelled out towards 


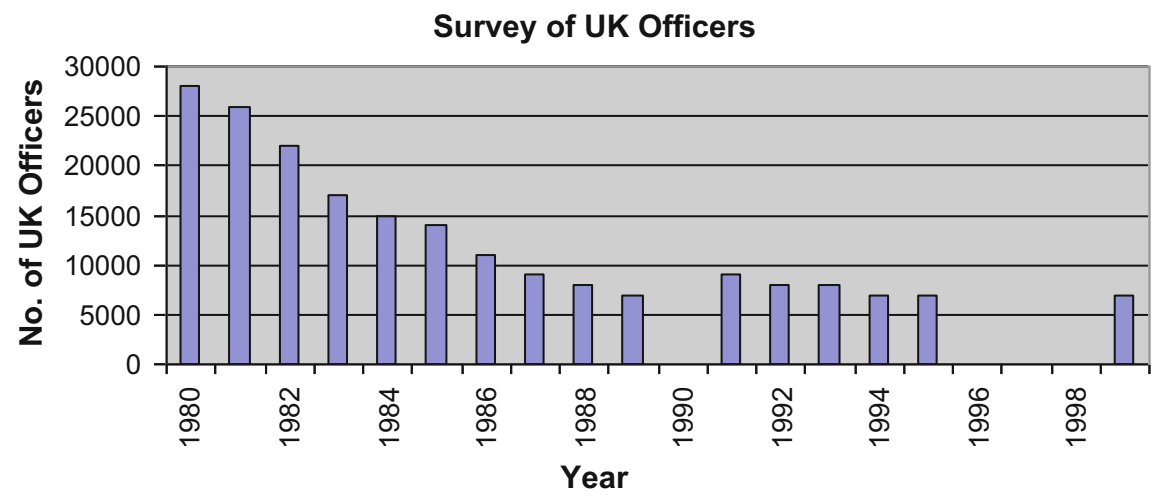

Fig. 13.4 The number of British officers employed in the UK fleet between 1980 and 1998. Source: UK Chamber of Shipping (adapted and recreated by author from Brownrigg et al. 2001)

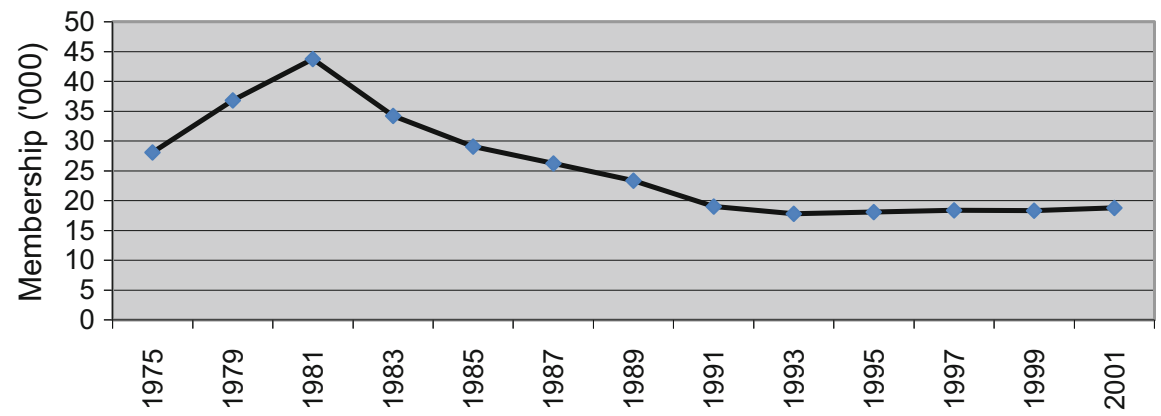

Fig. 13.5 NUMAST membership trend between 1975 and 2001. Source: Created by author from Nautilus International annual reports, 1975-2001, The British Certification Officer, https://tinyurl. com/wgqeakw [24/11/2019]

the end of the century (see also Brownrigg et al. 2001; Leggate and McConville 2005).

The third area of decline, and one which forms the core focus of this chapter, is union membership. Figure 13.5 shows the trend of membership for National Union of Marine, Aviation and Shipping Transport Officers (NUMAST), the key union for seafarer officers in Britain from the early 1980s to 2006. Union membership diminished during this period in tandem with the national shipping fleet, cadet recruitment and the number of officers employed in the British shipping fleet. The consistent decline across all these aspects of the industry is unsurprising since they are intimately intertwined and cross-dependent.

As union membership decreased, so did the union's capacity to effectively represent workers and ensure effective protection of labour standards and working conditions in an increasingly vulnerable labour market. These developments were not unique but broadly representative of the general predicament of labour in most advanced industrial countries. As Peters (2008, p. 85) observes, 
[...] over the past 25 years [starting from mid-1980s], the emergence of economic globalization and the consolidation of neoliberalism has profoundly altered the balance of power between capital and labour. Unions now find bargaining with firms and governments over collective agreements and social policy much more difficult, and all unions are under constant pressure to defend minimum standards of income and employment protection in labour markets.

The point expressed by many other labour market commentators like Peters is that challenges for labour cut across many sectors and, as in seafaring, they manifested themselves by creating difficulties in international labour organising, a drastic tip in the balance of bargaining power between workers and employers and by extension, increasing employment vulnerability for workers at different points along the global commodity supply chain (Munck 2002; Fiorito and Gallagher 2006; Lévesque and Murray 2006; Webster 2015).

Mark Dickinson, then president of NUMAST, was a major advocate for, and leader of, the amalgamation. He later became the NI General Secretary and in a 2006 interview stated that in the context of growing employer power and declining state support "... [unions] had to be innovative and think outside the box in order to remain effective and strong for [their] members". This was, according to him, and many of the key leaders leading the transformation, the key impetus for seeking greater collaboration with similar unions across national borders, leading to the creation of Nautilus International. Thus it was conceived out of the need to survive and continue to function effectively in a changing industry and labour market.

\section{The Nautilus International Project: Considering the Process, Motivation and Outcomes}

As explained earlier, the two formerly independent maritime unions that initiated the merger - the UK's National Union of Marine, Aviation and Shipping Transport Officers (NUMAST) and the Federatie van Werknemers in de Zeevaart (FWZ) of the Netherlands - came together and joined in 2009 to create a single cross-border union. This was the culmination of a lengthy process of negotiation and consultation spanning a decade beginning in the late 1990s (Gekara 2010a). Prior to the conception of the amalgamation, the two unions had enjoyed a long, close working relationship. This was partly due to geographic proximity and the fact that their two countries have long intertwined maritime histories but also, and perhaps more importantly, as explained by the union leaders, because Dutch and British seafarers have traditionally worked side by side on-board Anglo-Dutch owned/operated vessels. What makes their move unique and novel is that the two unions, which had been independent and organised in different countries, agreed not just to collaborate more closely, as most international union alliances do, but to largely dismantle their national structures. This included abandoning their individual national identities and foregoing their independence to form a regional union with a new identity and structure set up across international borders as a single entity. 
The separate histories of the two unions, prior to the amalgamation, present an informative case of national union restructuring, including mergers and splinters. The British arm of the union-Nautilus-UK - traces its roots to the Mercantile Marine Service Association (MMSA) in 1857. By 1920 the association had transformed itself through splinters, mergers and take-overs involving many other smaller marine unions. Further similar processes of restructuring over the following years resulted in the creation of NUMAST in 1985, when MMSA joined with the Merchant Navy and Airlines Officers Association (MNAOA) and the Radio and Electronics Officers' Union (REOU). Consequently, an inclusive union was created representing ship and airline officers and other shore-based maritime professionals. On the other side of the border FWZ had also gone through similar restructuring processes. Formed in 1901 by a group of officers at a bar in Amsterdam, the union grew and developed through mergers and take-overs culminating in the Federatie van Werknemers in de Zeevaart (FZW) in 1995. At that time Algemene Vakbond voor Zeevarenden (AVZ) the trade union for masters, officers and ratings on small merchant navy vessels and Vereniging van Kapiteins en Officieren ter Koopvaardij (VKO), mainly representing masters and officers on large merchant navy vessels, merged to form a wider union representing workers in the broader maritime profession. On both sides the restructuring seems to have involved a natural progression of mergers, beginning at the local and national level and eventually moving outward, across national borders. Later in 2011 and 2015 the new union further expanded with the joining of Unia, the Swiss maritime professionals' union and another Dutch seafarers' union-FNV Waterbouw, respectively. The commonly identified factors influencing union amalgamations including, declining memberships, reduced financial resources and political influence, strongly apply to the case of Nautilus International. The merger process was primarily driven by the need to regain political and financial ground in the industry's industrial relations, as the following interview extract shows:

[unions] reach a critical mass and they know they can't go on like this, they've got declining membership, rising costs and no resources and they need to do something about it... They cannot go on increasing membership fees indefinitely just to stay afloat...this is what has happened with us. (NI Leader 1 2006)

Whereas mergers, takeovers and amalgamations are common within national borders, the NI case, illustrates an important point, which I term here as 'exhausted national possibilities' whereby a major impetus is created for the search for crossborder partners and a need is prompted for initiating closer working relations. Seemingly, by the close of the twentieth Century, the two unions involved had exhausted local possibilities for further mergers, so that,

....there were no more suitable, like-minded unions to merge with locally.... By this time all those who could be part of us were already with us, so we had to look outside. (NI Leader $12009)$

This need illustrates the key point that national resources for labour organising are finite, particularly in the context of declining state protections and growing neoliberal policies in which business interests are preferenced over those of labour (Gekara 
2010b). Consequently, room for further growth must be sought from without. For example, as a result of a continuing decline in the pool of seafarers locally, the possibilities of expanding membership in the vicinity were rapidly diminished. It appears that by this point, the Dutch and British maritime professional union amalgamation was almost a natural progression because they "already had a very long-standing relationship" and it was therefore "an inevitable choice" (NI Leader $12009)$.

It was in this context that active negotiations commenced in the late 1990s and, after almost a decade, the two unions moved on from the framework of an ad hoc cross-border collaboration, prevalent in the industry, to a more defined and structured association. In October 2006, they respectively dropped their individual identities and became the Nautilus Federation (NF). From then on they adopted the names Nautilus UK and Nautilus NL respectively. This move to a federation constituted a significant move. Not only did it signal the intention of creating a stronger bond, forged with the common goal of regaining both political and financial influence in the negotiation for seafarers' rights and labour standards in the region, but it also gained sufficient status to influence events on the international stage.

The motivation for us was clear, we had lost a lot of ground and we could not afford to lose any more as our members depended on us... we had a responsibility as leaders to use every means to regain that ground and this was the most logical... (NI Leader 2 2010)

From the commencement of the negotiations the objective was to ultimately establish one single cross-border union. The NF was, therefore, meant as a temporary platform - a space for creating and testing the necessary structures for eventual full amalgamation. The federation period served three important functions. Firstly, it was during this time that the separate leaderships conducted final consultations and balloting to gain unequivocal grass-root approval for the eventual amalgamation. Secondly, it provided the space for rationalising and streamlining the two, hitherto, separate, and largely different organisational structures and creating one, which would enable the union to operate as one single entity transcending geo-political boundaries. Finally, it served as a platform for trialling the emerging structures for the new union. With regard to this last function, the NF stage was of great necessity, considering that there was till then no guiding model available for the kind of crossborder union merger envisaged by the leaders.

The Nautilus Federation was just a stage and was never meant to remain as a lasting structure, it served its purpose, an important one but our aim was to quickly and strategically progress towards a complete merger and a single union body... it was important, just like a trial phase towards a marriage if you like. (NI Leader 32010 )

Upon completion of the amalgamation process and the launch of the new union in May 2009, the Nautilus Federation was rendered dormant, with the provision that it would be reactivated as a temporary platform for initiating new national unions wishing to join Nautilus International in the future, as happened with the joining of Unia and FNV Waterbouw in 2011 and 2015 respectively. The organisational governance structure of 2010 resulted when the full merger was launched between the two principal partners. 
Under the new union, an inclusive cross-border governance structure was adopted, which merged the formally separate organisational structures in a way that sought to maximise the advantages of both (see Fig. 13.6). The governance structure consists of a General Meeting (GM) of all members, which takes place every four years, at the top, followed by the Council of the Union (CoU), made up of thirty-two elected members, twenty-four of whom are British and eight Dutch. Reporting to the $\mathrm{CoU}$ are several council committees, including the Resolutions, Establishments and the Professional and Technical Committees. The next most significant level below the CoU comprises two national committees made up of the elected council members (24 UK and $8 \mathrm{NL}$ ) plus extra members from the national secretariats in the two countries. Regular national conferences are held on both sides where important matters affecting specific national aims are discussed, including the election of national committee members and representatives to the CoU. The GM is the highest organ in the decision-making hierarchy of the union where all members are represented and debate on important issues affecting all members and from where the effective running of the union takes place. Any resolutions carried at the GM are binding on the $\mathrm{CoU}$ according to the Nautilus Rule Book,

The absolute control and administration of the affairs and property of the union and the furtherance of the objects of the union and the provision of all the benefits together with the necessary power to utilise union funds and monies shall be vested in the Council subject only to any direction of the Union given by its members at a general Meeting... (Rule 12.1)

The significance of the GM is that no important changes in the way the union is structured and operated may be effected without being discussed at the GM. For this reason, provision is made for the establishment of Special General Meetings (SGM) to handle important matters arising in-between the scheduled GMs. For example, a special GM was called on 30th June 2011, named the Rules General Meeting, to effect changes to the Rules in order to enable members of Unia (Switzerland union) to join NI. The national committees, on the other hand, "deal with policy issues relevant only to the specific country". The national committees also have the power to establish such further committees as necessary for the effective management and administration of the national branch (Rule 17.2).

The day-to-day management of the union is the responsibility of a General Secretary (GS) based in London. The GS is aided by National Assistant General Secretaries (AGS), based in the different countries represented coordinating several administrative departments. These departments oversee the implementation of various decisions and the running of the national branch. The national AGSs are also responsible for coordinating the activities of an Internal Senior Management Team that draws membership from the staff of the national administration. They also coordinate the activities of national administration teams from which an internal senior management team is constituted. This in turn, coordinates the activities of several joint committees, including a policy coordination committee, an industrial coordination seminar, a finance committee and a human resource committee. The idea behind this elaborate structure is that the management and governance of the union is as seamless as possible so as to 


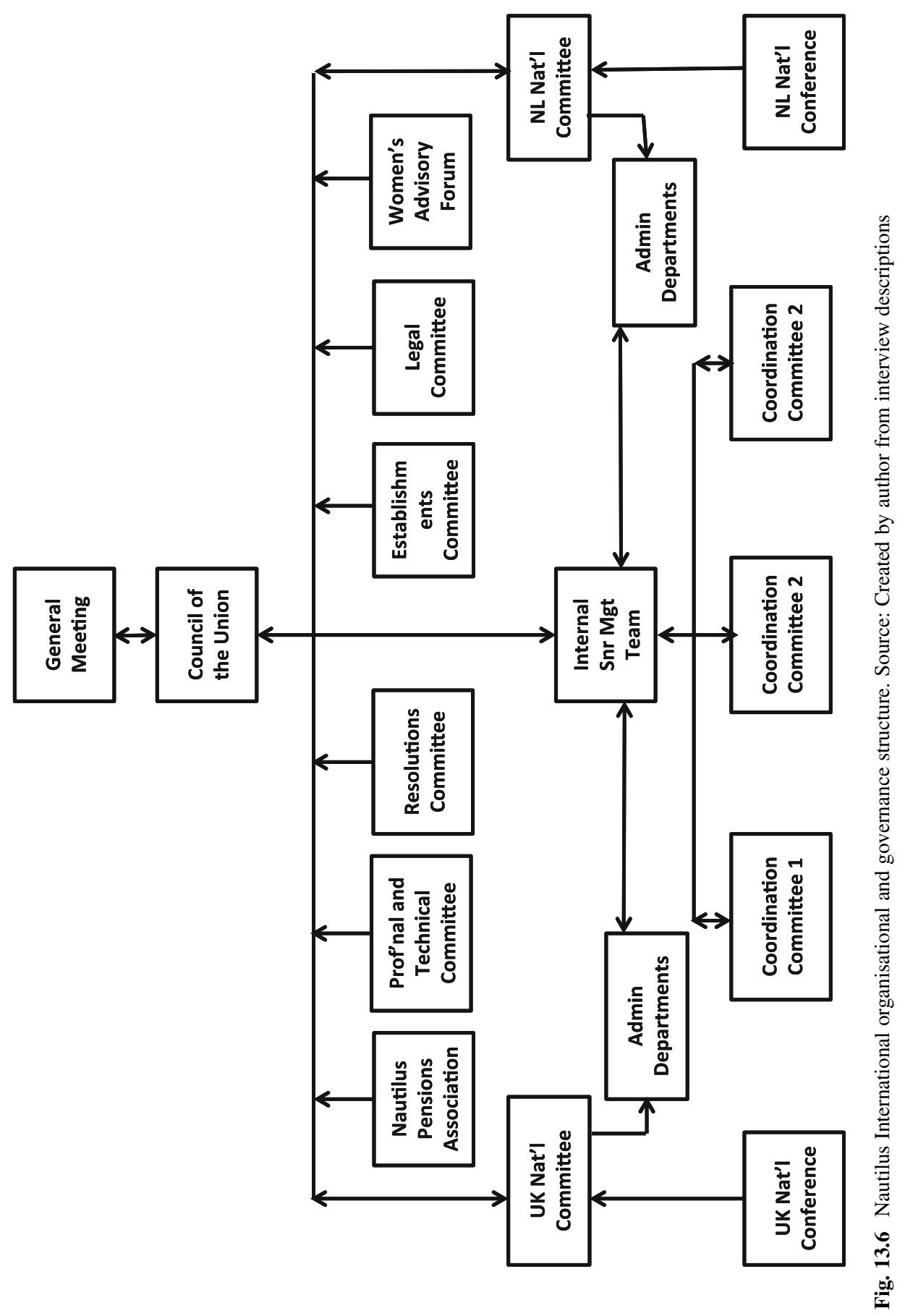


encourage in all the members from different countries the development of a real sense of belonging and a feeling of common identity.

\section{Concluding Assessment: Why Was the Merger Important and for Whom?}

In order to assess the successes and appreciate the challenges of adopting the new structures one has to first look at the context in which the union exists and operates and also its specific objectives. First, as established earlier, Nautilus International was born of the necessity to survive in a declining labour market with the associated decline in its representational capacity as a workers' union. In this regard, as observed by many labour market commentators, unions can only serve their core purpose of reducing inequality, improving jobs, and widening income distribution, if they can maintain and/or increase density and grow their effectiveness through wide bargaining coverage and coordination (see e.g. Peters 2008; Swenson 2002; Western 1997). Accordingly, the key driving objective for the leaders of the NI project is easily understood and was expressed by one of the leaders as the need,

... [to] have a strong voice in Brussels [and] more power in negotiating with national governments and ship owners. (NI leader 1 2009)

Regarding this aspect, the immediate obvious outcome of the merger was an increase in membership numbers, as is evident from the rise in figures between 2008 $(15,915)$ and $2009(22,518)$ when the merger came into effect, as illustrated in Fig. 13.7.

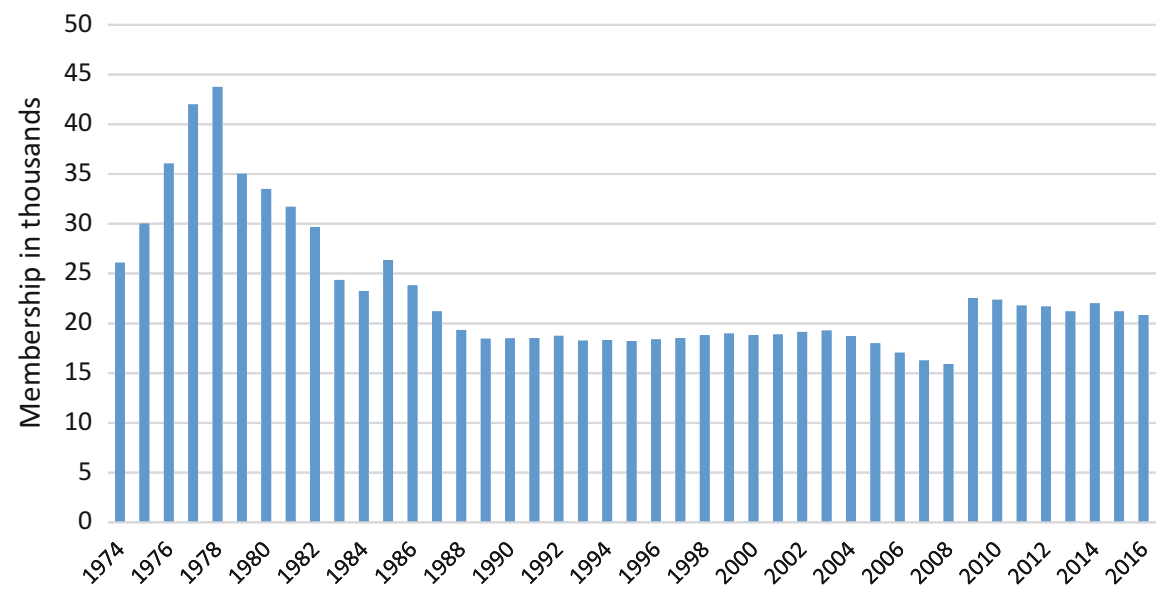

Fig. 13.7 Membership numbers pre and post-merger. Source: Created by author from Nautilus International annual reports, 1974-2016, The British Certification Officer, https://tinyurl.com/ wgqeakw [24/11/1919] 


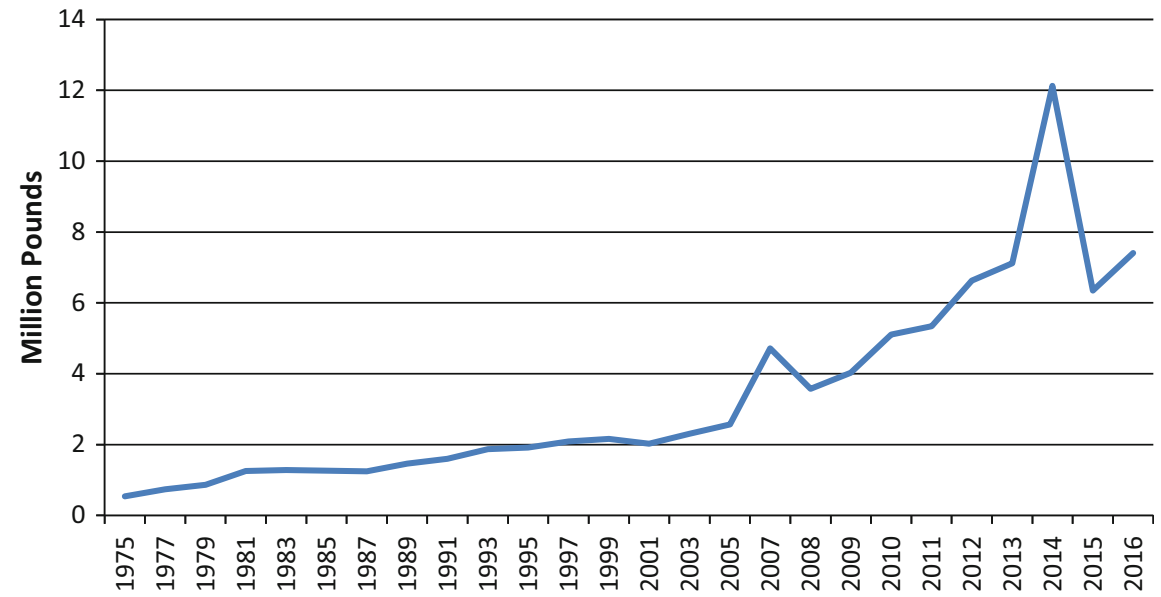

Fig. 13.8 NI income and expenditure. Source: Created by author from Nautilus International annual reports, 1975-2016, The British Certification Officer, https://tinyurl.com/wgqeakw [24/11/ 2019]

Another important and measurable indicator of success was the improvement in the collective financial resources of the union. Figure 13.8 shows that the financial income statement steadily increased from 2009 after a sudden dip between 2007 and 2009. The union's income is calculated according to members' subscriptions and contributions, memorandum agreements from employers and investment transfers (based on details in the annual returns) consequently it is easy to see how the pooling of financial sources from all members of the union could have such an immediate impact in comparison with the state of the NUMAST income before the merger. To illustrate, in 2008 the then NUMAST received an income of GBP 3,576,494. In 2010, after the merger the figure grew to GBP 5,101,440 and to GBP 7,118,205 in 2013. ${ }^{1}$

Against the set objectives, it is important to address the question of why this merger matters and for whom it is important. Perhaps the most important gains which lie behind the figures and numbers are captured in the interviews with the leaders and some of the members in 2010, during the first GM of members of the NI. The leaders were particularly encouraged by what they perceived as a significant rejuvenation of their organising and bargaining capacity with one of the leaders observing that the increase in membership was "... definitely a big boost in our negotiating power with employers" (NI Leader 2 2010). There was a general feeling at the GM that employers were already beginning to take notice and, as one council

\footnotetext{
${ }^{1}$ The Jump from 2013 to GBP $12,128,956$ was due to a large lump-sum arrears transfer from the NI Netherlands office. The figure goes back to the normal trajectory in 2015.
} 
member put it, "...realise that we are one body of workers. . they cannot win by bargaining with small, individual national unions" (NI Council member 2010).

This observation, however, also represents Nautilus's main challenge and the one which undermines the extent of its power. While employers, i.e. shipping companies, are extensively global in their operation and have the ability to exploit the breadth of both political and economic resources available internationally with little restriction, unions have always been limited by their nationally embedded and pathdependent structures (see Gekara et al. 2013). Even with such cross-border mergers where they have tried, with notable effect, to emulate the seamless transnational workings of global business, the union still finds its influence limited to the individual countries it is organised across, i.e. Great Britain, the Netherlands and Switzerland. The second and more important challenge related to this limitation is the fact that, even collectively, the union represents and operates in a generally declining labour market where the number of seafarers will continue to decrease over time with natural attritions, since there is currently little replenishment occurring through new training.

Nevertheless, whilst recognising the challenges inherent in the situation, NI has adopted an unambiguous view of its role and a specific strategy for effective representation of its members. It sees its strategy as less expansionary and more targeted both in its spatial scope and its functional objectives. Its practical regional focus in Europe is not only to work towards maintaining and improving labour standards primarily for European seafarers but also for all seafarers, by lobbying national, regional and international policy as well as through strategic negotiations with employers. It has adopted the social partnership approach where it seeks to work with employers and governments towards a concerted goal of continuously improving workers' work and employment terms and conditions- to ensure high labour standards. According to one of the leaders in an informal conversation with the researcher in 2011,

It is much easier to work with employers, work with government and Brussels and the rest of them. At the end of the day, we have to make them realise that we face the same challenges, at the end of the day, and they have realised...they need well qualified and motivated seafarers but to do this they must train and they must offer good conditions... as simple as that really. (NI Leader 1 2010]

As demonstrated in the foregoing analysis, Nautilus International, provides an illuminating case study of the significant challenges faced by labour in the current context of the ever increasing, exploitative power of capital. It reveals the potential strengths of global cross-border organising and sends one important message- that nothing less than globally coordinated, strategic alliances will help counter the power of capital and secure the future of workers' rights. 


\section{References}

Alderton, T., M. Bloor, E. Kahveci, T. Lane, H. Sampson, M. Thomas, N. Winchester, B. Wu, and M. Zhao. 2004. The Global Seafarer: Living and Working Conditions in a Globalised Industry. London: ILO.

Beck, U. 2005. Power in the Global Age: A New Global Political Economy. Cambridge: Polity.

Brownrigg, M., G. Dawe, M. Mann, and P. Weston. 2001. Developments in UK Shipping: The Tonnage Tax. Maritime Policy and Management 28 (3): 213-223.

Carlisle, R. 1981. Sovereignty for Sale: The Origins and Evolution of the Panamanian and Liberian Flags of Convenience. Annapolis: Naval Institute Press.

Chomsky, N. 2017. Global Discontents. London: Penguin Books.

DeSombre, E.R. 2006. Flagging Standards: Globalization and Environmental, Safety, and Labor Regulations at Sea. London: MIT Press.

Dunning, J. 1993. Multinational Enterprises in a Global Economy. Workingham: Addison-Wesley. Fiorito, J., and V.C. Gallagher. 2006. Renewal in the United Faculty of Florida: Class War in Paradise? Labor Studies Journal 31 (3): 39-64.

Gardner, B., M. Naim, B. Obando-Rojas, and S. Pettit. 2001. Maintaining the Maritime Skills Base: Does the Government Have a Realistic Strategy? Maritime Policy and Management 28 (4): 347-360.

Gekara, V.O. 2010a. Union Renewal Through Cross-Border Merger: Rationale, Processes and Challenges. European Journal of Industrial Relations 16 (4): 385-394.

- 2010b. The Stamp of Neoliberalism on the UK Tonnage Tax and the Implications for British Seafaring. Marine Policy 34 (3): 487-494.

Gekara, V.O., I.L. Acejo, and H. Sampson. 2013. Re-Imagining Global Union Representation Under Globalisation: A Case of Seafaring Labour and the Nautilus International Cross-border Merger. Global Labour Journal 4 (3): 167-185.

Giddens, A. 2002. Runaway World; How Globalisation is Reshaping Our Lives. London: Profile Books.

Harvey, D. 2005. A Brief History of Neoliberalism. Oxford: OUP.

Held, D., A. McGrew, D. Goldblatt, and J. Perraton. 1999. Global Transformations: Politics, Economics and Culture. Cambridge: Polity Press.

Kahveci, E., and T. Nichols. 2006. The Other Car Workers: Work, Organisation and Technology in the Maritime Car Carriers Industry. Basingstoke: Macmillan.

Leggate, H., and McConville. 2005. Tonnage Tax: Is it Working? Maritime Policy and Management 32 (2): 177-186.

Lévesque, C., and G. Murray. 2006. How Do Unions Renew? Paths to Union Renewal. Labour Studies Journal 31 (3): 1-13.

Lillie, N. 2006. A Global Union for Global Workers: Collective Bargaining and Regulatory Politics in Maritime Shipping. London: Routledge.

McConville, J. 1999. The United Kingdom Shipping Industry and International Regulation. In Transport Regulation Matters, ed. J. McConville, 78-97. London: Pinter.

Metaxas, B.N. 1985. Flags of Convenience: A Study of Internationalisation. Aldershot: Gower.

Munck, R. 2002. Globalisation and Labour: The New Great Transformation. London: Zed Books Ltd.

Nautilus International Annual Reports (Various year 1974-2016), the British Certification Officer On-line., https://tinyurl.com/wgqeakw [24/11/2019]

Perraton, J. 2019. The Scope and Implications of Globalisation. In The Handbook of Globalisation, ed. J. Michie, 3rd ed., 50-96. Elgar Online.

Peters, J. 2008. Labour Market Deregulation and the Decline of Labour Power in North America and Western Europe. Policy and Society 27 (1): 83-98.

Sampson, H., and T. Schroeder. 2006. In the Wake of the Wave: Globalisation, Networks, and the Experiences of Transmigrant Seafarers in Northern Germany. Global Networks 6 (1): 61-80.

Scholte, J.A. 2000. Globalisation: A Critical Introduction. New York: Palgrave. 
Stiglitz, J. 2002. Globalisation and Its Discontents. London: Penguin Books.

Strange, S. 1996. The Retreat of the State: The Diffusion of Power in the World Economy. Cambridge: Cambridge University Press.

Swenson, P. 2002. Capitalists Against Markets. The Making of Labor Markets and Welfare States in the United States and Sweden. New York: Oxford University Press.

Webster, E. 2015. Labour After Globalisation: Old and New Sources of Power. Institute of Social and Economic Research (ISER), Rhodes University. ISER Working Paper No. 2015/1

Western, B. 1997. Between Class and Market: Postwar Unionization in the Capitalist Democracies. Princeton, NJ: Princeton University Press.

Open Access This chapter is licensed under the terms of the Creative Commons Attribution 4.0 International License (http://creativecommons.org/licenses/by/4.0/), which permits use, sharing, adaptation, distribution and reproduction in any medium or format, as long as you give appropriate credit to the original author(s) and the source, provide a link to the Creative Commons licence and indicate if changes were made.

The images or other third party material in this chapter are included in the chapter's Creative Commons licence, unless indicated otherwise in a credit line to the material. If material is not included in the chapter's Creative Commons licence and your intended use is not permitted by statutory regulation or exceeds the permitted use, you will need to obtain permission directly from the copyright holder. 